\title{
SZEMÉLYES VAGY TUDOMÁNYOS? KOSÁRY DOMOKOS ÉS SZABAD GYÖRGY VITÁJÁNAK ELŐZMÉNYEI
}

\author{
PERSONAL OR SCIENTIFIC? \\ THE PRECEDENTS OF THE DOMOKOS KOSÁRY \\ AND GYÖRGY SZABAD DEBATES
}

\author{
Hermann Róbert \\ az MTA doktora, a Hadtörténeti Intézet és Múzeum parancsnokának tudományos helyettese, egyetemi tanár \\ Hadtörténeti Intézet és Múzeum; Károli Gáspár Református Egyetem \\ hermann.robert@mail.militaria.hu
}

\section{ÖSSZEFOGLALÁS}

A neoabszolutizmus politikatörténetének kutatásában az 1945, s főleg az 1948 utáni időszakban komoly visszaesés mutatkozott. A korszakkal foglalkozó szerzők jobbára a Kossuth-emigráció történetének egyes periódusairól, vagy ezzel szoros összefüggésben, a hazai függetlenségi és alkotmányos mozgalmakról írtak, s nemigen foglalkoztak a "másik oldal”, a Habsburg-kormányzat történetével vagy a hazai politikai életen belüli egyéb tendenciákkal.

E szempontból is korszakosnak volt mondható az a nagymonográfia, amely 1967-ben (éppen a kiegyezés 100. évfordulóján) jelent meg Szabad György tollából, Forradalom és kiegyezés válaszútján (1860-61) címmel. A mű kétségkívül az 1945 után indult és a polgári átalakulás korával foglalkozó magyar történésznemzedék egyik legjelentősebb alkotása.

1969. október 27-én és 28-án került sor Szabad György akadémiai doktori védésére, amelynek alapjául ez a munka szolgált. A három opponens (Sőtér István, Kovács Endre és Kosáry Domokos) mindegyike elismerően szólt a védés alapjául szolgáló monográfiáról. A három opponens közül Kosáryé volt a legkritikusabb álláspont - ugyanakkor egyáltalán nem volt barátságtalan.

Mégis, ez a bírálat, pontosabban ennek a Történelmi Szemlében való közzététele vezetett ahhoz a Kosáry és Szabad között lezajlott vitához, amely koncepcionális ellentétből személyes ellenségeskedéssé fajult. Magának a vitának a története jól ismert, ezért inkább arra érdemes figyelni, volt-e valamifajta előjele ennek az igen hevessé váló konfliktusnak? A tanulmány áttekinti e vita előzményeit, kezdve a két vitapartner 1948 utáni eltérő sorsától Kosárynak a tudományos életbe történő visszatéréséig. Végkövetkeztetése szerint a két személyiség közötti koncepcionális ellentét már Szabad védése előtt jól kitapintható volt. Azaz, nem azon kell csodálkoznunk, hogy kettejük vitája kibontakozott, hanem az lett volna a csoda, ha ez a vita nem következik be.

\section{ABSTRACT}

In the research of the political history of neo-absolutism, there was a serious decline in 1945, and especially in the post-1948 period. The writers of the time mostly wrote about certain periods of the history of the Kossuth emigration or in close association to it the Hungarian independence 
and constitutional movements and did not deal with the history of the 'other side', the Habsburg government or other tendencies within domestic political life.

From this point of view, the great monograph that was published in 1967 (the $100^{\text {th }}$ anniversary of the Austro-Hungarian Compromise of 1867) was published by György Szabad, entitled At the Crossroads of Revolution and Compromise (1860-61). The book is undoubtedly one of the most significant opuses of the generation of Hungarian historians starting after 1945, and researching the age of bourgeois transformation.

On October 27 and 28, 1969, György Szabad defended his academic doctoral thesis, which was based on this work. The three opponents (István Sötér, Endre Kovács and Domokos Kosáry) all praised the monograph. Among the three opponents, Kosáry had the most critical position but he was not unfriendly at all.

Yet, this criticism, more precisely, the publication of it in the historical quarterly, Történelmi Szemle (Historical Review) led to a debate between Kosáry and Szabad, which, from a conceptual disagreement became a personal enmity. The story of the debate itself is well known, so it is better to look for any indications for this very fierce conflict. The study reviews the antecedents of this debate starting with the diverging faith of the two debating partners after 1948 to Kosáry's return to scientific life. It concludes that the conceptual conflict between the two personalities had been already well-known before Szabad's academic doctoral defence. That is, there is no reason to be surprised that their dispute unfolded at all but it would have been a miracle if this dispute did not happen.

Kulcsszavak: magyar polgári átalakulás, 1848-49. évi forradalom és szabadságharc, 1860-1861 évi országgyűlés, neoabszolutizmus, kiegyezés, Kossuth-emigráció, magyar nemesség, nemzetiségi kérdés, Kádár-rendszer

Keywords: Hungarian burgeois transformation, 1848-49 Revolution and War of Independence, Parliament of 1860-1861, neo-absolutism, compromise, Kossuth emigration, Hungarian nobility, nationality issue, Kádár system

A neoabszolutizmus politikatörténetének kutatásában az 1945, s föleg az 1948 utáni időszakban komoly visszaesés mutatkozott. A korszakkal foglalkozó szerzők jobbára a Kossuth-emigráció történetének egyes periódusairól vagy ezzel szoros összefüggésben a hazai függetlenségi és alkotmányos mozgalmakról írtak, s nemigen foglalkoztak a „,másik oldal”, a Habsburg-kormányzat történetével vagy a hazai politikai életen belüli egyéb tendenciákkal.

E szempontból is korszakosnak volt mondható az a nagymonográfia, amely 1967-ben (éppen a kiegyezés 100. évfordulóján) jelent meg Szabad György tollából, Forradalom és kiegyezés válaszútján (1860-61) címmel. (Szabad György még 1964-ben zárta le a kéziratot.) A mü kétségkívül az 1945 után indult és a polgári átalakulás korával foglalkozó magyar történésznemzedék egyik legjelentősebb alkotása. A munka címe és tartalma önmagában állásfoglalás volt a kiegyezés és a dualista rendszer értékelése körül felújuló vitákban, s a kádári konszolidáció során aktuálpolitikai felhangokat is kapott. 
1969. október 27-én és 28-án került sor Szabad György akadémiai doktori védésére, amelynek alapjául ez a munka szolgált. A három opponens mindegyike elismerően szólt a védés alapjául szolgáló monográfiáról. Sőtér István főleg a monográfia irodalomtörténeti hozadékairól beszélt, Kovács Endre elsősorban az emigráció s azon belül a Kossuth politikájával kapcsolatos részeket elemezte, $\mathrm{s}$ néhol bírálta. Így kissé túlzottan rózsaszínűnek értékelte a Kossuth nemzetiségpolitikai koncepciójának fejlődéséről festett képet. Ezt követte Kosáry Domokos bírálata. A három opponens közül az övé volt a legkritikusabb álláspont - ugyanakkor egyáltalán nem volt barátságtalan.

Mégis, ez a bírálat, pontosabban ennek a Történelmi Szemlében való közzététele vezetett ahhoz a Kosáry és Szabad között lezajlott vitához, amely koncepcionális ellentétből személyes ellenségeskedéssé fajult. Magának a vitának a története jó ismert, ezért inkább arra érdemes figyelni, volt-e valamifajta elöjele ennek az igen hevessé váló konfliktusnak.

Kezdjük azzal, hogy Szabad és Kosáry pályafutásában több a különbség, mint a hasonlóság. Kosáry 1913-ban, az első világháború előtti utolsó békeévben született, selmecbányai polgárcsalád sarjaként; Szabad már a trianoni diktátumot követően, a királyi Romániában látta meg a napvilágot egy magyar identitású zsidó család sarjaként 1924-ben. Kosáry családja 1919-ben, Szabadé 1932-ben települt át Magyarországra. Kosáry jó másfél évtizeddel korábban kezdte meg tudományos pályafutását, még a Horthy-korszakban, Szabadot pedig a numerus clausus és a zsidótörvények miatt még az egyetemre sem vették fel 1942-ben, s csak 1946-ban kezdhette meg egyetemi tanulmányait. Emlékezései szerint többek között Kosáryt is hallgatta. Míg Kosáryt 1949-ben megpróbálták kiszorítani a szakmából, Szabad 1951-től az Eötvös Loránd Tudományegyetem aspiránsa volt - éppen a Kosáry lehetetlenné tételében föszerepet játszó Andics Erzsébet szakmai irányítása mellett.

1956-ban Szabad is ott volt a Petőfi Kör történészvitáján, de szóhoz nem jutott, ezért írásban nyújtotta be hozzászólását. Ebben többek között követelte a szakmában méltatlanul mellőzött történészek, köztük Kosáry rehabilitálását. Szabad tagja lett az Oktatók Ideiglenes forradalmi Bizottságának is, amely követelte a régi oktatók, köztük Kosáry visszavételét az egyetemre, illetve a rákosista oktatók eltávolítását. Mindketten ott voltak az Akadémia utcában a Pártközpont felé tartó egyetemi küldöttség soraiban halálosan megsebesült I. Tóth Zoltán temetésén - a szertartás előtt Szabad „vezényelte” a Himnusz eléneklését, s Kosáry mondta a búcsúbeszédet.

Kosáry Domokosnak 1957-es letartóztatását követően egy ideig a neve sem jelenhetett meg a nyilvánosságban. A Századok hasábjain egyedül Pach Zsigmond Pál hivatkozott rá egy, Görgei Artúr 1849. augusztusi tevékenységét bemutató, nem túl magas színvonalú tanulmányban, természetesen negatív szövegösszefüggésben. Tudomásunk szerint az egyetlen olyan személy, aki megpróbálkozott a „tilalom” áthágásával, Szabad György volt. Emlékezései szerint a Kossuth és az angol egyensúlypolitika viszonyát taglaló angol nyelvü tanulmányának magyar 
változatát a Századok szerkesztősége azért utasította vissza, mert annak jegyzetanyagában Kosáry egyik munkájára hivatkozott. 1961-ben pedig talán az első olyan szerző volt, aki Kosáry egyik tanulmányára hivatkozott a Századok hasábjain.

Maga Szabad szintén ki volt téve némi vegzálásnak 1956 után, de komolyabb retorzió nem érte. Noha az életútinterjúban jobbára sérelmeiről és az őt ért szakmai bántalmakról emlékezik meg (amilyenekből valóban akadt nagy számmal), szakmai reputációját jelzi, hogy az 1956-1990 közötti négy reprezentatív történeti összefoglaló (a Molnár Erik szerkesztette Magyarország története, az egyetemi tankönyv 4. kötete, a Magyarország története képekben, illetve a „tízkötetes” Magyarország története 6. kötete) mindegyikében ő írta meg a neoabszolutizmus történetét, sőt, közülük kettőben ő írta meg az 1867-1890 közötti időszakot is.

Első kisebb pengeváltásukra az új (tízkötetes/húszkötetes) Magyarország története feudális kori köteteinek periodizációjáról szóló, 1966. március 4-én megtartott vitán került sor. A fő referátumot tartó Heckenast Gusztáv amellett érvelt, hogy a kései feudalizmuson belül korábban korszakhatárként elfogadott 1790 helyett gazdaság-, társadalom- és művelődéstörténeti érvek alapján is helyesebb lenne az 1760-as évek közepére tenni a korszak- vagy szakaszhatárt, a kapitalista Magyarország történetének kezdő dátumaként pedig a korábbi 1849-es korszakhatár helyett 1848 márciusát javasolta.

A vitában mind Szabad, mind Kosáry rész vett. Közülük Szabad szólalt fel előbb, s pártolta Heckenast javaslatát az 1790-es korszakhatárnak előbbre, az 1760-as évek közepére történő áthelyezésével kapcsolatban. Ugyanakkor a feudális időszak negyedik korszakánál azt javasolta, hogy „középpontba állítva 1790-et”, annak végpontja az 1820-1830-as évek fordulójáig terjedjen, ezt pedig kövesse egy átmeneti korszak, amely az 1830-as évekkel indulna és 1867-ig tartana, középpontjában az 1848-as forradalommal. „Ragadjuk meg az átmenetet önálló egységként, tartalmának lényegét tekintve az átmenetet megvalósító polgári forradalom korszakaként" - javasolta, s hivatkozott arra, hogy mind az olasz polgári, mind a marxista történetírás egyetlen egységként kezeli a Risorgimento korszakát. „Ne vágjuk át a feudális főkorszakot a kapitalista fökorszakhoz csatlakoztató ízületet periódushatár közbeiktatásával, hanem oly módon oldjuk meg a tárgyalást, hogy a forradalmi átmenetnek a legfontosabb összefüggéseket a történelem valóságában egységes folyamattá zárkóztató fóive töretlen maradjon." Hozzátette, hogy a periodizáció akkor jó, ha a lényegest kiemeli; ez pedig nemcsak szokványos módon, határvonal meghúzásával, hanem „a kiemelendő középpontba állításával” is megvalósítható. Javaslatának elfogadása „nem mosná el 1848 történelmi fordulatának jelentőségét, hanem éppen kidomborítaná azt" (Szabad György felszólalása, in: Varga, 1968, 121-123.).

Kosáry Domokos - a referátumok felkért előadóit nem számítva - tizenkettedikként szólalt fel a vitában; Heckenast Gusztáv referátuma után az ő hozzászólása volt a legterjedelmesebb. Kosáry kifejtette, hogy egy olyan munkában, 
amelynek a politikai eseménytörténetet is el kell mondania, elképzelhetetlen az a megoldás, hogy „ölelkező korszakokat” mutassanak be; valamilyen szilárd igazodási pontot mindenképpen választani kell. Korábbi és későbbi munkáihoz hasonlóan hangsúlyozta, hogy miután „Magyarország nem valami magános óceáni szigeten, másoktól távol élte végig történetének máig érő fejezeteit”, a periodizálásban okvetlenül tekintettel kell lenni a nemzetközi eseményekre is. Miután végigvette a feudális korszak periodizálásával kapcsolatos javaslatokat, cáfolva az 1760-as évek közepi periódushatárral kapcsolatos érveket, határozottan az 1790es szakaszhatár megtartása mellett foglalt állást. Tágabb perspektívában felhívta a figyelmet arra, hogy 1789 francia forradalmára a magyar 1790, az 1830. júliusi párizsi forradalomra a magyar reformmozgalom megélénkülése, 1848 februárjának francia forradalmára pedig a magyar 1848 volt a magyar válasz. A feudalizmus végpontjaként 1848 tavaszát jelölte meg, mondván, hogy ezzel a feudalizmus kora lezárult, és többé nem tért vissza. „A szabadságharc és minden, ami utána következett, már a polgári korszak első fejezetébe tartozik. A forradalom és a szabadságharc egymáshoz kapcsolódó, de nem azonos fogalmak."

Ezután reflektált Szabad javaslatára „a magyar polgári forradalom kora” című periódus beiktatásáról. Kifejtette, hogy ha Szabad ilyen címen monográfiát írna, azzal messzemenően egyetértene, s arról is biztosítja őt, „hogy ha e monográfiát megírná, akkor e nyilván kitünő könyv első olvasói közé számíthatna engem". Ami azonban helyes egy monográfiában, az nem az egy tízkötetes összefoglalóban. A probléma, folytatta, itt ugyanaz, mint 1790 körül, sőt, annál egyértelmübb. Itt ugyanis nemcsak alkorszakok határáról van szó, hanem „még magasabb szinten” társadalmi formációk határáról is. „A feudalizmus mint rendszer 1848-ban zárul le Magyarországon (ha maradványai tovább élnek is), és a kapitalizmus mint rendszer 1848-ban lép a helyébe, nem 1849-ben, nem 1867-ben, és nem is 1848 elött, ha feltételeinek kialakulása meg is figyelhető már korábban.” A feudalizmus záró és a kapitalizmus kezdő fejezetét sok minden, például a szereplők életpályája is egymáshoz füzi. „Mégis azt kell mondanunk, hogy a feudalizmus és a kapitalizmus közé nem illeszthető be egy harmadik, átmeneti formáció, mert ilyet nem ismerünk, és hogy így a történeti fejlődés egészét tekintve, nagyobb távlatból 1848 a döntő korszakhatár." (Kosáry Domokos felszólalása, in: Varga, 1968, 146-157.)

Kosáry szövege igen határozott - de nem nevezhető ellenségesnek, sőt, Szabad képességeit illetően kimondottan udvarias. A periodizáció tekintetében, legyen szó akár 1790, akár 1830, akár 1848 jelentőségének megítéléséről, nem volt közöttük érdemi különbség. Szabadnak az 1760-as évek közepi periódushatárral kapcsolatos pártoló megnyilvánulása nem 1790 „lebecsüléséből”, sokkal inkább a hozzászólásában kifejtett, a döntő fontosságú események centrumba állítását pártoló szemléletéből fakadt. A tízkötetes végső periodizációját tekintve Kosáry javaslata „ment át”: a 4-5. kötet között 1790, az 5-6. kötet között 1848 lett a határvonal. Megjegyzendő, hogy a vita ugyan az 1849-ig terjedő korszak perio- 
dizációjáról szólt, de gyakorlatilag már ekkor eldőlt a későbbi időszak korszakolása is. Ugyanakkor elméleti szinten csak a korszak- és a periódushatárokról folyt az eszmecsere - az egyes korszakok tárgyalásának szempontjairól, netalán azok újraértékeléséről nem. Így éppen az 1790-1867 közötti időszak maradt afféle „mostohagyerek”, ahol aztán - a szerzők személyének sajátos kiválasztása miatt egymás mellé került egy kimondottan korszerü reformkori összefoglaló (Gergely András és Vörös Károly tollából), és egy, már a saját korában is erősen korszerütlen 1848-49-es fejezet (Spira György munkája). Ez utóbbit pedig Szabad György szintén nagy ívü és korszerü összefoglalója követte.

Szabad és Kosáry ellentétes felfogása immár nyíltan manifesztálódott az egyetemi tankönyv negyedik, az 1849-1918 közötti időszakot bemutató kötetének vitájában, 1969. szeptember 22-én. A kötetben Szabad írta meg az 1849-1867 közötti neoabszolutista rendszer történetét.

Szabad fejezetéhez először Spira György szólt hozzá, s nagyobbrészt az 18601861. évi események problematikájával foglalkozott. Véleménye szerint Teleki László programja társadalmi bázis híján volt kudarcra ítélve. „Annak a ténynek, hogy a nemzetiségi kérdést az 1860-as évek elején nem sikerült megoldani, nem alkalmi okai voltak, hanem a magyar politikai vezetőréteg zömének állásfoglalása: inkább választották a megegyezést a Habsburgokkal, mint a nemzetiségekkel. Az 1861-es országgyülés azonban nem találhatott rá a kibontakozás itt jelzett útjára, mivel a Habsburgok még nem voltak készek a megegyezésre.” Emellett hiányolta a kiegyezés expressis verbis értékelését. Véleménye szerint „mind Deáknak, mind Kossuthnak igazat lehet adni; a kiegyezés az egyedüli reális lépés volt az 1860-as években, amellyel azonban Magyarország hozzákötötte szekerét a felbomlásra ítélt Habsburg-birodalomhoz, s ennek utóbb minden következményét vállalnia kellett." Ha a kiegyezés 1848 -hoz képest visszalépés volt, a 48 előtti állapotokhoz viszonyítva eredmény, és ez mindenekelött 48-nak volt köszönhetö.

A Spira után felszólaló Kosáry „történetírásunk nagy elörelépésének” nevezte a könyvet, s külön kiemelte ,az abszolutizmuskori részek gondos felépítését és kidolgozását”. Elismeréssel szólt az 1867 utáni pártalakulások, illetve a pártok társadalmi bázisának ábrázolásáról. Ennek alapján kiderül, mondta, hogy közvetlenül 1867 után lényegében ugyanaz a társadalmi valóság állt az összes párt mögött, s hogy a 67-es és a 48-as táborban egyaránt találhatók retrográd és haladó elemek, illetve törekvések. Emellett utalt Eötvös József nemzetiségi programjára $\mathrm{s}$ vele szemben a függetlenségi sajtó századvégi intranzigens nacionalizmusára. Véleménye szerint a pártalakulásokat, a pártok társadalmi összetételét, politikai és gazdasági programjukat kölcsönös összefüggésükben kell vizsgálni. Ennek során hangsúlyozta a közjogi nemesi ellenzék korszerütlen gazdasági elképzeléseit. Kosáry szerint a tankönyvben nem körvonalazódik elég határozottan az a tendencia, ,amely a magyar nemességet mint politikai vezetőréteget 1849 -től kezdve a forradalomtól egyre távolabb vitte, s végül szembefordította vele". Úgy tűnik, 
mintha a negatív jelenségek egyéni kivételek lennének. Kosáry szerint az abszolutizmus kori belső cezúrákat élesebben kellene megvonni: az elkeseredett egyéni vállalkozások 1853-ig, politikai hullámvölgy, majd 1859-től a fellendülés időszaka. A kiegyezés - mondotta - „nemcsak a magyar uralkodó osztály többségének akarata volt, hanem az osztrák uralkodó osztály többségének is; vagyis megfelelt az adott kor erőviszonyainak. Helytelen tehát illúzióként említeni. A magyar uralkodó osztály azon politikai célkitűzése volt illúzió, hogy társadalmi és nemzeti hegemóniáját az adott országkeretek között egyszer s mindenkorra biztosítsa.”

Szabad válaszában csak azokra a hozzászólásokra tért ki, amelyek bírálták munkáját. Kosárynak válaszolva azt fejtegette, „hogy 1848/49 után korántsem volt eldöntött kérdés, hogy a kisbirtokos és birtoktalan nemesség, ill. nemesi értelmiség mekkora hányada fog a kapitalista korszakban a konzervatív irányzathoz csatlakozni. A hatvanas években mindaddig, amíg a nemesi rétegek jelentős része reménykedett a nemzeti önrendelkezés lehetőségében, különböző rétegei, ill. az azokat reprezentáló politikai erők között heves küzdelem folyt, mégpedig nem csupán nemzeti, hanem társadalmi kérdésekben is. Ezzel a belső küzdelemmel és a nemességet még jellemző belső ingadozással függ össze Teleki tragédiája is; így nem helytálló a jelentősebb bázist nélkülöző, szinte magányos Telekiről alkotott régi elképzelés, amit a vitában Spira elevenített fel. Nem indokolatlan erről a küzdelemről és ingadozásról szólni, ha végül a retrográd tendencia került is felül, döntően annak következtében, hogy a magyar hegemóniát a nemesség már csak a Habsburg-hatalommal kötött kompromisszum útján látta biztosítottnak.”

Ami a kiegyezés értékelését illeti, a tankönyv egésze tartózkodott az elemzéstől különválasztott értékelésektől. A kiegyezés értékelését is elsősorban feltételei kialakulásával, tartalmával, az általa létrehozott rendszer funkcionálásával foglalkozó fejezetek nyújtják. Ezt követően idézte $A$ kiegyezés tartalma címü alfejezet nyitó bekezdésének értékelését (,A kiegyezés az önkényuralmi rendszert felszámoló, új alkotmányos államberendezkedést kialakító, a birodalom egyik felében osztrák-német, a másikban magyar politikai hegemóniát biztosító kompromisszum volt."); majd pedig a 163. oldalon található részt, amely a kiegyezéses rendszer teremtette társadalmi és nemzeti uralmi formáról szól (Somogyi, 1969, 1320-1327.).

Ezt követően került sor 1969. október 10-én a Magyar Tudományos Akadémia Történettudományi Intézetében Hanák Péter, Lackó Miklós és Ránki György Gazdaság, társadalom, társadalmi-politikai gondolkodás Magyarországon a kapitalizmus korában címü, a tízkötetes Magyarország története előmunkálatának tekinthető kéziratának vitájára. Ez a kézirat már nem a periodizáció meghatározását, hanem az 1848-1945 közötti időszakot tárgyaló kötetek (a 6-7-8. kötet) tartalmi kérdéseiben történő „iránymutatást” célozta. Ha a feudalizmus periodizációjáról szóló vitaindító és maga a vita is még csak mellékesen szólt 1848-49-ről, a három szerző tanulmánya már nemigen foglalkozott a forradalom és szabadságharc történetével, s meglehetösen röviden intézte el a neoabszolutizmus korát is. 
A kézirat vitájában huszonöten szólaltak fel, közülük az első Szabad György volt. Alapvetően elismerően nyilatkozott a kéziratról, csupán a reformkori gazdasági növekedés rátáját illetően szállt vitába, mivel azt magasabbra becsülte a kézirat szerzőinél. Emellett felhívta a figyelmet arra, hogy az 1790-1848 közötti periódusban a magyar társadalomban mélyreható változások mentek végbe. Külön kitért a reformellenzék gazdaságpolitikai koncepciójára, amely Magyarország és Ausztria gazdasági kapcsolatát egyenrangú felek vámszövetsége alapján képzelte el. Végül a tőkeimport problémájával kapcsolatban azt fejtegette, hogy Ausztria a tárgyalt időszakban nem csupán hitelforrás, de egyben hitelközvetítő is volt, mivel maga is tőkebehozatalra szorult, s a közvetítésnek nemcsak ára, de felára is volt (Szabad György felszólalása, in: Spira, 1971, 87-96.).

Szabad felszólalása a viszonylag hosszabbak közé tartozott, de ismét Kosáryé volt a leghosszabb. (Szabad egy későbbi megjegyzése alapján feltételezhető, hogy eredeti formájában rövidebb lehetett.) Kosáry előbb azt fejtegette, hogy a kézirat mennyi mindenben haladta meg az 1950-es évek történetszemléletét, majd hat pontban foglalta össze megjegyzéseit. Elöször arról beszélt, hogy Magyarország 18. századi relatív gazdasági elmaradottsága nem az 1754 . évi vámrendelet következménye - ez inkább a már meglévő tendenciákat erősítette fel, de nem volt okozója az elmaradottságnak.

Második megjegyzése a nacionalizmus és liberalizmus kapcsolatára vonatkozott; azt fejtegette, hogy a nacionalizmus nemesi formája volt az, ami a 19. század első felében elkezdett összekapcsolódni a polgári törekvésekkel, s a reformmozgalomban az 1840-es években még viszonylag kisebb negatívumot hordozott, de utóbb, amikor a liberalizmus és a nacionalizmus került konfliktusba egymással, „a konfliktusban a liberalizmus maradt alul”.

A kiegyezéssel kapcsolatban egyetértett a kézirat azon megfogalmazásával, hogy „nem a kiegyezés hozta létre a magyar uralkodó osztály konzervatív hajlamát és hegemóniára való törekvését, hanem fordítva: magyar részről ez hozta létre a kiegyezést". A továbbiakban azt fejtegette, hogy a kiegyezéssel szembeni azon ellenérvet, hogy az meghosszabbította a Habsburg-monarchia életét, hozzákötötte Magyarország sorsát, és így elkerülhetetlenül az 1918. évi felbomláshoz vezetett, nem erős, hanem gyenge ellenérvnek tekinti. „Mert mi bizonyítaná, vagy akár valószínűsítené, hogy a régi, soknemzetiségü ország, úgy ahogy volt, a kiegyezés nélkül inkább és tovább fennmaradhatott volna?" Lehet, hogy a robbanásszerü felbomlás nem volt szükségszerü, s elvileg elképzelhető volt egy olyan folyamat, amelynek során ,,a magyar uralkodó osztály hegemóniáját fokozatosan feladják és elismerik azt, hogy az országon belül más, külön nemzetek is léteznek". Csakhogy, Kosáry szerint ezt a magyar uralkodó osztály soha nem akceptálta, s ebben nem 1867 akadályozta meg. Az is elképzelhető, hogy a kiegyezés nélkül a bomlás már előbb fenyegetővé vált volna. Kosáry szerint az elutasító magatartás tekintetében nem volt érdemi különbség a kiegyezéspártiak és az azt 
ellenzők között - mindketten magyar hegemóniát akartak, csak az egyik Ausztriával együtt, a másik attól függetlenül. Dicsérte a kéziratnak a dualizmus kori gazdasági fejlődéssel kapcsolatos részét, s a Szabad által is említett tőkeimportra csak röviden utalt azzal, hogy az az adott helyzetben elkerülhetetlen volt.

Negyedik megjegyzése a dualizmus kori társadalomfejlődés rajzát dicsérte. Itt viszonylag részletesen szólt a magyar nemességről, s kiemelte, hogy ,azon jelentős történelmi szerep hatása alatt, amelyet a reformkor és 1848 köznemessége, különösen annak kitünő politikai garnitúrája játszott, ma is akad, aki hajlamos úgy gondolni, hogy a magyar nemességre a múlt században valami különleges történelmi kivételként, nem egészen állnak az uralkodó osztályokra általában érvényes megállapítások, így az sem áll, hogy a magyar nemesség, mint a francia burzsoázia, 1848 illetve 1849 után visszahátrált volna a forradalomtól. Pedig hátrálása nézetem szerint elég nyilvánvaló."

A továbbiakban foglalkozott a magyar nemesség egyediségét bizonyító ellenérvekkel. Szerinte önmagában az, hogy a nemesség számos, olykor ellentétes, egymással küzdő tendenciákat képviselő rétegekből állt, nem jelenti azt, hogy „e széles mezőnyön belül” ne lett volna „hangadó réteg és fő tendencia”; azaz, volt nemesség mint gyüjtőfogalom és történelmi tényező.

A másik ellenérv az, hogy a nemességen belül aránylag csekély volt a jobb módú birtokos, a számbeli többség nem volt jobbágytartó, csak a kiváltságai különböztették meg más, nem nemes rétegektöl. „De éppen az a csak, a kiváltságoké, itt a fontos. Ennek a társadalmi tudati befolyása itt a fontos." Kosáry szerint a részletes vizsgálatok nem azt bizonyítják, „hogy a vagyontalansággal együtt nő a demokrácia, vagy éppen a forradalom iránti hajlandóság"; s utalt arra, hogy az ólmosbotos kisnemesség milyen negatív szerepet játszott a reformkori választási küzdelmekben.

Végül, Kosáry szerint, az az ellenérv sem áll, hogy „,a nemesség annál demokratikusabb, minél nagyobb egy társadalmon belül a számbeli aránya”. Bizonyos tekintetben ez inkább fordítva áll: a nemesség nagy száma miatt olyan alsó- és középszintű pozíciók is a birtokába jutnak, amelyek más társadalmakban nem kiváltságos elemek kezére kerülnek.

Az ötödik megjegyzése a századforduló újkonzervatív szellemi mozgalmaira utalva védelmébe vette Szekfü Gyula 1918 előtti történetírói működését, s őt magát is a progresszióhoz sorolta a retrográd tendenciákkal szemben. Majd - némi csúsztatással - a Szekfú által a köznemességről a Három nemzedék hasábjain festett képet (szakmai alapon) bíráló Mályusz Elemért (név nélkül) „a köznemesi felfogás egyik szóvivője"-ként aposztrofálta. Utolsó megjegyzése az 1918-1920 közötti Duna-táji rendezéssel kapcsolatos fejtegetéseket dicsérte. (Kosáry Domokos felszólalása in Spira, 1971, 128-143.)

A vitaülés két és fél héttel előzte meg Szabad akadémiai doktori védését, s Kosárynak a nemesség történeti szerepével kapcsolatos téves nézeteket bíráló hozzá- 
szólása meglehető egyértelmüséggel Szabadnak szólt. De ilyen volt a francia burzsoázia 1848, illetve a magyar nemesség 1849 utáni magatartásának párhuzamba állítása is, hiszen ezzel Kosáry ki nem mondva ugyan, de Szabad egyik fö tézisét tagadta, ti. azt, hogy 1860-1861-ben még nyitott kérdés volt, hogy a magyar nemesség melyik úton indul el: a demokratizálás és a szomszéd népekkel történő megegyezés vagy az Ausztriával való kiegyezés útján. Az is nyilvánvaló, hogy Szabad a liberalizmus és nacionalizmus viszonyáról is másként gondolkozott, a kiegyezés megítélése tekintetében pedig teljes egészében eltért a véleményük.

Ha a fentiekben leírtakat összevetjük a Történelmi Szemle hasábjain kibontakozó vitában leírtakkal, jól látható, hogy a két személyiség közötti koncepcionális ellentét már Szabad védése elött jól kitapintható volt. Azaz, nem azon kell csodálkoznunk, hogy kettejük vitája kibontakozott, hanem az lett volna a csoda, ha ez a vita nem következik be.

\section{IRODALOM}

Dénes I. Z. (szerk.) (2018): Kitörés a kánonból: Szabad György történetírói munkássága. Budapest: Ráció Kiadó

Gerő A. (szerk.) (2016): A polgári átalakulásért. Emlékkötet Szabad György tiszteletére. Budapest: Közép- és Kelet-Európai Történelem és Társadalom Kutatásáért Közalapítvány

Kosáry D. (1969): Szabadságharc és kiegyezés között. Reflexiók egy témához. Történelmi Szemle, 12, 3-4, 337-344. https://tti.btk.mta.hu/images/kiadvanyok/folyoiratok/tsz/tsz1969_3-4/kosary.pdf

Kosáry D. (1971): Néhány módszertani megjegyzés egy régi válaszra. Történelmi Szemle, XIV, 1-2, 260-264. https://ti.btk.mta.hu/images/kiadvanyok/folyoiratok/tsz/tsz1971_1-2/kosary.pdf

Somogyi É. (1969): Vita a „Magyarország története az abszolutizmus és a dualizmus korában 1849-1918" c. egyetemi tankönyv kéziratáról. Századok, 103, 1320-1327.

Spira Gy. (szerk.) (1971): Vita Magyarország kapitalizmuskori fejlödéséröl. (Értekezések a történeti tudományok köréből 55) Budapest: Akadémiai Kiadó

Szabad Gy. (1967): Forradalom és kiegyezés válaszútján (1860-61). Budapest: Akadémiai Kiadó

Szabad Gy. (1971): A kiegyezés előtörténetéhez. (Felelet Kosáry Domokos „reflexióira”). Történelmi Szemle, XIV, 1-2, 254-259. https://ti.btk.mta.hu/images/kiadvanyok/folyoiratok/tsz/ tsz1971_1-2/szabad.pdf

Szabad Gy. (1972): Tények és módszerek. (Felelet Kosáry Domokos újabb bírálatára). Történelmi Szemle, XV, 1-2, 256-258. https://tti.btk.mta.hu/images/kiadvanyok/folyoiratok/tsz/tsz1972_12/szabad.pdf

Szabad Gy. (2017): Aradtól az Országgyülésig. Pavlovits Miklós interjúja Szabad Györggyel 19911992. Szakmai szempontból ellenőrizte és a jegyzeteket készítette Csorba L. (Tények és tanúk) Budapest: Magvető Kiadó

Varga J. (szerk.) (1968): Vita a feudális kori magyar történelem periodizációjáról. (Értekezések a történeti tudományok köréből 45) Budapest: Akadémiai Kiadó 